\title{
Competition and Cooperation in European Professional Club Football
}

Authors' contribution:

A) conception and design of the study

B) acquisition of data

C) analysis and interpretation of data

D) manuscript preparation

E) obtaining funding

\author{
Lili Kassay $^{\text {A-D }}$, Gábor Géczi ${ }^{\text {D-E }}$
}

University of Physical Education, Hungary

\begin{abstract}
The aim of the article is to highlight the theoretical assumption that the relative competitive disadvantage between markets with different maximum sizes can be partially counteracted with strategic thinking and business-like operations. The research question presented in this article is whether there are any management tools available for clubs which they can use to improve their business competitiveness above and beyond the limitations of their maximum market size. According to the research hypothesis, there is such a tool available for clubs: the management and operation of a football club in a well-organized and business-like manner. The method of analysis is the so-called Grounded Theory (Glaser, \& Strauss, 1967; Locke, 2001), which is an abstract analytical schema with a systematic data analysis process. The data collection incorporates desk research, comparative analysis, organizational review, and in-depth interviews. The results are presented according to the following dimensions: a) relevance of the research question; b) specification of groups of relevant management tools; c) the role of the national football association in the process of market development; $d$ ) the role of the owners in this process; and e) how the structure of the sector and its operating processes can guarantee the efficient utilization of all the material resources which have been plowed into the sector over the last four to five years. According to the conclusions, the creation of an operating system and club model that allows for the utilization of resources - maximized market revenues and governmental sources - in the most effective way is an unavoidable challenge. The formation of the sustainable operations of clubs is fundamentally influenced by club owners. An inspection of the interaction between club owners, head coaches, and players is a key task in the process of creating a new club model.

business-like operation, competitiveness, relevant management tools
\end{abstract}

\section{Introduction}

The business model of European club football is financially unsustainable. Despite the fact that revenues are increasing for European football in general, there are many football markets which are not experiencing this phenomenon (UEFA, 2009, 2010, 2012, 2013). This imbalance among the markets of the peer group has been increasing (Humphreys, 2002; Mehra, \& Zuercher, 2006; Owen et al., 2007). The clubs of the small and medium markets have to compete with all of the teams of the top markets at an international level to earn a fixed amount of money. However, they are not competitive from a business and financial 
perspective as their own market resources are not sufficient to cover players' wages when compared with all of the clubs of the top markets (UEFA, 2009, 2010, 2012, 2013).

Based on the review of the available literature and industry data, the responsiveness and convergence of small to medium markets are hindered not only by limited market size - the real obstacle to their improvement is their failure to effectively (or failure to attempt to) (Kassay, 2012) assess their own markets (Kassay, 2013), to define challenging but achievable targets and develop appropriate strategies (Kassay, 2011; Kassay, \& Géczi, 2014), and to implement appropriate strategies through business-like operations (Kassay, \& Géczi, 2015).

In order to analyze the above issues, we intend to carry out a comprehensive study. The first part of the planned research was recently finished. It contained two phases: in the first phase, secondary sources were used for analysis; the second phase can be regarded as a pilot study of the planned organizational and corporate governance review. This paper is based on the findings of the latter. The theoretical background of our investigation and the methodological considerations which led to the choice of the methods used in the research are also presented in the paper.

\section{Objectives}

The purpose of this article is to present the results of a pilot project in Hungarian football which had the aim of verifying the validity of the planned audit by the teams of the first and second leagues. The findings of the pilot study were collected with in-depth interviews with club owners and chief executives from the Hungarian second league. The authors intend to provide answers to the following research question: Are there any management tools available for clubs which they can use to improve their business competitiveness above and beyond the limitations of their maximum market size? It is assumed that there is indeed a tool available for clubs: the management and operation of a football club in a well-organized and business-like manner.

\section{Defining the major terms}

Since the terms used in our paper might be applied with different meanings, we think it would be effective to clarify in which sense they are used here.

1. Competitive balance in sports: the unpredictability of results during a defined period of competition/ league play (UEFA, 2009, p. 40).

2. Business competitiveness: the measurement of the success of a business along the two dimensions of the maintenance or increase of its market share and its financial results (Chikán, \& Czakó, 2008).

3. Sustainability: a complex strategic approach integrating economic, social, and environmental aspects by management through long-term value generation, supplying the required resources (BSCDH, 2012).

4. Axioms: "Money scores goals, but goals are not profitable"; "There is a strong correlation between high net transfer balance and success on the field"; "There is no correlation between economic performance and on-field performance" (https://www.atkearney.com, 2010, pp. 4-5).

5. Closed system: all factors of competition are generated in the domestic market (league) and affect local conditions.

6. Dual interpretation of competition: the service offering of professional sports is not generated without competitors. Competitors compete on the field; however, they cooperate off the field in order to support the sustainability of competition. 


\section{Theoretical foundation}

During the theoretical foundation of the research, we assessed the factors of competition from an integrative approach and assessed the small and medium market clubs' chances of competing through a conceptual framework.

The theoretical foundation of the research assesses the factors of competition (Porter, 2008) from an integrative approach (Figure 1) and assesses the small and medium market clubs' chances of competing through a conceptual framework (Figure 2).

Based on an assessment of the competition factors (Figure 1), each market is examined as a closed system in the following respects: the market of competition and its size; the nature of competition and cooperation; and the competitive balance between a given number of clubs (1). New entrants are represented by new owners of a club or existing owners who enact a change in their management approach. These potential changes may reshape the competitive structure of a championship in a relatively short time (2).

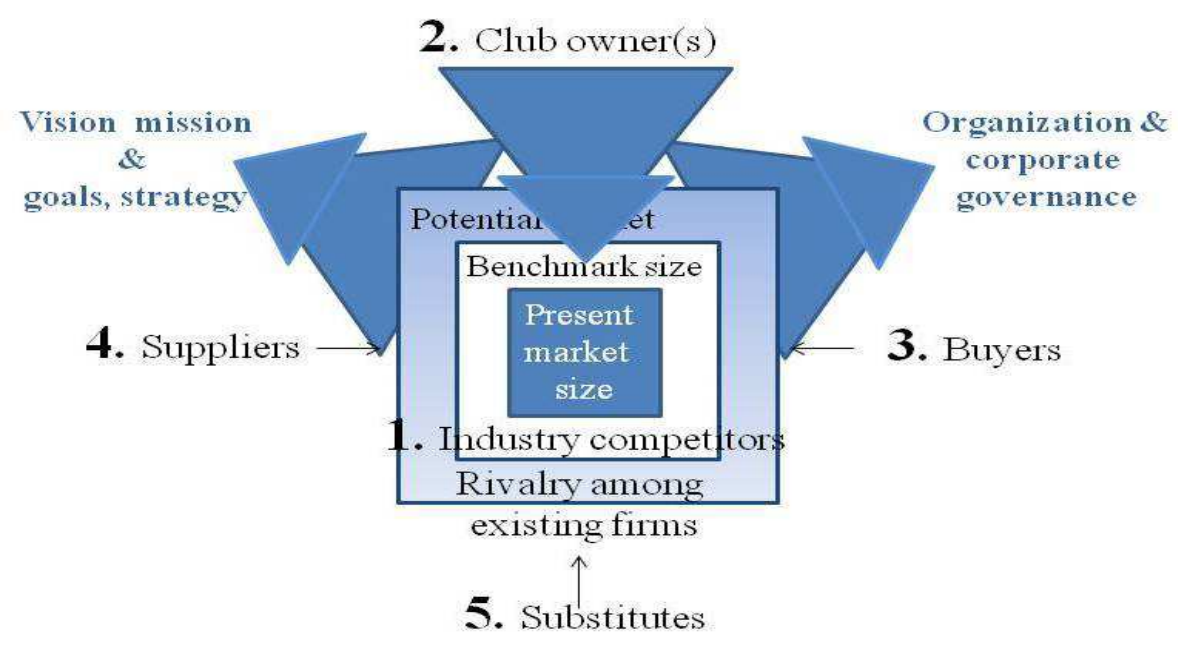

Figure 1. Factors of competition and their sensitive borders from an integrative approach

Source: own study based on Porter's Five Forces Framework.

The club owners' interpretation of success and the links between sports results and revenue generation (relations of service provider - buyers - market position) primarily affect the organizational structure and operations of a club (4). The club owners' approach to achieving sports results (club - players - politics market competition) shapes the vision of the club and how the competitive strategy is implemented (3).

The conceptual framework - the other aspect of the theoretical foundation - provides input regarding the interpretation of the issues of competitiveness and financial sustainability, as well as the development of responses to challenges facing small and medium markets (Table 1). Although the majority of the European first-tier clubs are rivals and do business in the medium, small, and micro markets, their weighted (or average) revenue share is much less than that of their European club counterparts. If they want to challenge top or large clubs on and off the pitch, they need to earn more money - but how?

Table 1. Distribution of income by markets and breakdown of revenue by type

\begin{tabular}{lcccccc}
\hline & \multicolumn{3}{c}{ Distribution of income by markets } & \multicolumn{2}{c}{ Breakdown of revenue by type } \\
\cline { 2 - 7 } & Broad-casting & Sponsorship & Gate receipts & Commercial & Market shares & Club shares \\
\hline Top & $88.1 \%$ & $61.5 \%$ & $70.4 \%$ & $35.0 \%$ & $68.5 \%$ & $13.4 \%$ \\
Large & $11.3 \%$ & $32.5 \%$ & $27.6 \%$ & $51.6 \%$ & $27.1 \%$ & $31.0 \%$ \\
Medium & $\mathbf{0 . 5 \%}$ & $\mathbf{4 . 7 \%}$ & $\mathbf{1 . 7 \%}$ & $\mathbf{1 0 . 1 \%}$ & $\mathbf{3 . 5 \%}$ & $\mathbf{2 1 . 5 \%}$ \\
Small & $0.1 \%$ & $1.1 \%$ & $0.3 \%$ & $2.6 \%$ & $0.8 \%$ & $19.9 \%$ \\
Micro & $0.0 \%$ & $0.2 \%$ & $0.1 \%$ & $0.7 \%$ & $0.2 \%$ & $14.2 \%$ \\
\hline
\end{tabular}

Source: own study based on UEFA, 2009. 
The analysis is structured as follows: domestic markets (closed system); international comparison (player transfers and business competitiveness); and opportunities in and limitations to entering international competitions (Champions League, Europa League) (Figure 2).

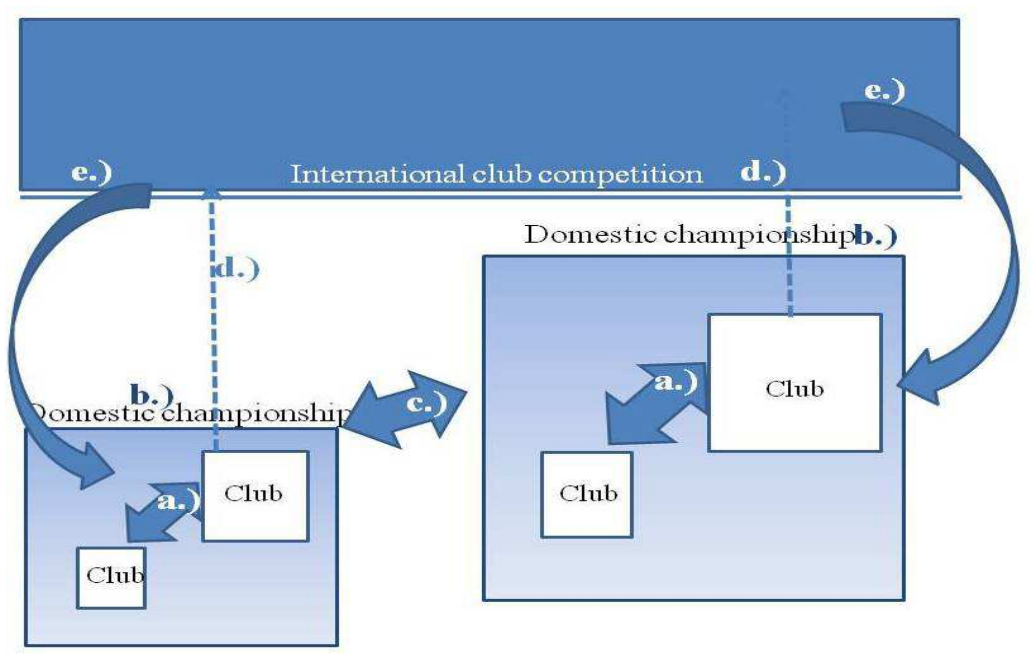

Figure 2. Factors Football clubs' competition and competitive balance circle

Source: own study.

We assess the factors of competition that can be influenced by the club and the association of clubs (leagues) directly. These factors are interpreted within the framework of country conditions and as contributors to the exploitation of current opportunities and the generation of new ones (closed system). The competitiveness of clubs (a) in a given championship adds up to the competitive balance and maximized market potential of the championship (b).

The competitiveness of championships (c) deserves attention due to the intensively globalized competition for players. Clubs in top competitive positions in each championship face differing chances of entering international markets (d) apart from opportunities provided by European governing rules. Those able to generate prize income in international club competitions (through existing competitiveness in the player market) may develop a competitive advantage in their domestic championship beyond the limitations of the local market (e). The existing balance of competition may shrink to a lower level as a consequence.

\section{Methods}

The method of analysis is the Grounded Theory (Glaser, \& Strauss, 1967; Locke, 2001), which is an abstract analytical schema with a systematic data analysis process; its data collection incorporates desk research, comparative analysis, organizational review, and in-depth interviews.

The Grounded Theory method allowed each first-tier championship to be analyzed independently as closed systems. In the first phase of the first part of the research, secondary sources were used for analysis. Desk research data collection supported the potential consumer market size estimation of clubs and championships, as well as benchmark information for comparative assessment. A professional estimate was used to define the potential consumer market sizes of clubs and their championships, as well as the ranking of competitiveness resulting from the comparative assessment of benchmark leagues. We assessed the competitiveness ranking of the examined championships against benchmark leagues, as well as teams' chances of entering international competitions (Champions League, Europa League) based on calculated competitiveness scores. The same approach was used to assess the competitiveness of clubs in given leagues, their competitiveness ranking, and the balance of competition in different leagues. 
The organizational and corporate governance review was based on pre-defined analytical aspects and examined through the use of structured interviews with operating executives of clubs according to the two pillars of the theoretical foundation of the research. In considering the nature of the Grounded Theory method, it was necessary to clarify the scope of the organizational and corporate governance review and to measure its relevance - through in-depth interviews with seven representatives and experts - before executing it. The panel members with whom we conducted the interviews (which were part of the pre-test phase of the review) were representatives and professionals in the sector and the governing body in Hungary (six persons in total) (Peeters, \& Szymanski, 2012). The findings of the pilot study were collected through in-depth interviews with these representatives and through audits and interviews with club owners and chief executives from the Hungarian second leagues (three persons in total).

Due to the systematic nature of data collection and analysis, the analysis will be carried out on the clubs themselves (Hungarian First and Second Tier) to assess the question of how they compare with each other and benchmark clubs.

\section{Results and discussion}

The findings of our research show that the interviewees confirmed the relevance of the research question and supplemented it further by mentioning the role of the national football association in the development of their market, which is primarily based on public funding.

In their opinion, there are management tools available to clubs which they can use to improve their business competitiveness, regardless of their club or market size (small or medium markets).

According to the results, the interviewees agreed on three types of relevant management tool groups:

1. The mission and vision of the club created by the owner and the view of the role of ownership and its relationship with public funding;

2. The interdependence of strategies for sports and business and the establishment of a long-term planning method; and

3. The club owner's view of the concept of club operation and the relationship between the club and its host community.

An additional finding from the in-depth interviews with representatives and experts was that it is important to assess the role of the national football association in the market development process, as this process is primarily based on public funding in the case of small and/ or medium markets, although all or most of the clubs operate like business organizations.

The opinion of the interviewees about the sports business competitiveness of the Hungarian first-tier championship's clubs is based on the interviewees' own benchmarks or expert estimations (e.g., GDP, number of inhabitants, the power of the benchmark leagues, average level of stadium capacity utilization). The results of the interviewees' benchmarks are interpreted by an operating cash flow approach ${ }^{1}$. The clubs' direct and indirect market revenues - from customers, sponsors, and central incomes from sponsors and broadcasters - can be calculated, establishing the maximum amount of money available to be spent on players' wages. According to the benchmarks, the budgets of the clubs in the Hungarian first-tier division are lower than those of their international competitors' budgets. This fact may ultimately influence the results of the matches.

The owners of the clubs in the Hungarian first-tier division are the sector's weak points; it is a fundamental issue as to whether they are reliable owners with enough money to spend on their clubs. They or their managing directors should be aware of the fact that it is impossible to run a profitable operation based on their present internal and external capabilities, although the macro environment is very supportive.

\footnotetext{
${ }^{1}$ Operating cash flow approach $=$ income and expenses incurred from the core business of the clubs.
} 
Over the past four or five years, significant amounts of money have been poured into the Hungarian football sector. However, its structure and operating processes are not able to guarantee the conscious, workmanlike, and efficient utilization of these material resources by the stakeholders. All the interviewees agreed that the national governing body's involvement in the reorganization of Hungarian football on the club level is indispensable. The interviewees share the view that it is necessary to create and introduce business and operating models for the clubs. These models should be built up along common strategic goals, taking into account the demands of the governing body financing the reorganization.

\section{Conclusion}

The creation of an operating system and club model that allows for the utilization of resources maximized market revenues and governmental sources - in the most effective way is an unavoidable challenge (Csáki et al., 2014; Vincze et al., 2008).

The formation of the sustainable operation of clubs is fundamentally influenced by club owners. Their mission and vision, shareholder engagement, and perspective regarding of state resources are decisive in this process.

The inspection of the interaction between club owners, head coaches, and players is a key task in the process of creating a new club model. A company-like operation is influenced by the owners' approach to the structure of the squad and their funding and, in addition, by their approach to the duality of their clubs' objectives in both sports and business.

The approach of club owners to the links between company-like operations and the host community and fans of a club is decisive in assessing the owners' perspective regarding to public funds.

The structure and content of the planned audit in the second part of the research project will be shaped in light of the results from the interviews with experts and representatives as explained above. This review covers the following questions:

1. Does the club strive toward its long-term goals? Does it operate in a formal structure? Is its operation based on formal work rules?

2. Are the organization's management processes arranged? Do these processes complement each other?

3. Does the club have an established human resources management concept? Does the club consciously use human resource management tools? In order to test the validity of the review before using it in domestic and international markets, it is necessary to check the validity of the questionnaire used in the research this questionnaire's validity.

\section{REFERENCES}

BSCDH (The Business Council for Sustainable Development in Hungary) (2012). Ajánlás vezetőknek. A vállalati fenntarthatóság komplex értelmezése /Recommendation for business leaders. The complex interpretation of corporate sustainability/. Retrieved from: http://bcsdh.hu

Chikán, A., Czakó, E. (2008). Versenyképesség - ahogyan a vállalatvezetők látják. Versenyképesség kutatás címü mühelytanulmány sorozat /Competitiveness - as the companies' executives see Research working paper entiteled Competitiveness Series/, 49. Budapest. Retrieved from: http://www.unicorvinus.hu/fileadmin/user_upload/hu/kutatokozpontok/versenykepesseg/MUHELYTANULMANYOK_pdf-ben_157/49_mht_Chikan_Czako.pdf

Csáki, I., Géczi, G., Kassay, L., Déri, D., Révész, L., Zalai, D., \& Bognár, J. (2014). The new system of the talent development program in Hungarian soccer. Biomedical Human Kinetics, 6(1), 74-83.

Glaser, B.G., \& Strauss, A.L. (1967). The Discovery of Grounded Theory. Chicago, USA: Aldine.

Humphreys, B.D. (2002). Alternative Measures of Competitive Balance in Sport Leagues. Journal of Sports Economics, $3(2), 133-148$. 
Kassay, L., Gergely, I., \& Géczi, G. (2015). A magyarországi hivatásos labdarúgó klubok körében lefolytatott audit validálási folyamata /Validation process of an audit recorded among the Hungarian professional football clubs/. In A. Borbély, P. Hamar, \& M. Kotányi (Eds.), Színes sporttudomány. Debreceni Campus Nonprofit Közhasznú Kft. Debrecen, Hungary.

Kassay, L., \& Géczi, G. (2014). Verseny-egyensúlytalanság és fenntarthatatlan üzleti modell az európai labdarúgásban /The Competitive Imbalance in and Unsustainable Business Models of European Football/. Magyar Sporttudományi Szemle, 15(57).

Kassay, L. (2013). A labdarúgó NB I. piaci pozíciója nemzetközi összehasonlításban /Market position of the Hungarian Football League in international comparison/. Marketing \& Menedzsment, 47(4), 55-64.

Kassay, L. (2012). A sportszórakoztatás nézőért kiált /Sports entertainment industry calls for spectators/. Marketing \& Menedzsment, 46(4), 26-35.

Kassay, L. (2011). Csapatsportágak versenye a fogyasztókért. Sportágak versenye. Magyar Sporttudományi Füzetek III (pp. 129-143). ISBN 978-963-87701-9-6.

Kearney, A.T. (2010). Is European Football Too Popular to Fail? EU Football Sustainability Study 2010. Retrieved from https:/www.atkearney.com/documents/10192/651284/Is+European+Football+Too+Popular+to+Fail/682120f815a1-4bba-a946-786457d8e61b

Locke, K.D. (2001). Grounded Theory in Management Research. London, UK: SAGE Publications Ltd.

Mehra, S.K., \& Zuercher, T.J. (2006). Striking Out "Competitive Balance" in Sports, Antitrust, and Intellectual Property. Berkley Technology Law Journal, 21(4), 1499-1546.

Owen, P.D., Ryan, M., \& Weatherston, C.R. (2007). Measuring Competitive Balance in Professional Team Sports Using the Herfindahl-Hirschman Index: A Cautionary Note. Review of Industrial Organization, 31(4), 289-302.

Peeters, T., \& Szymanski, S. (2012). Vertical restraints in soccer: Financial Fair Play and the English Premier League. Research Paper 2012-028. University of Antwerp, City Campus.

Porter, M.E. (2008). The Five Competitive Forces That Shape Strategy. Harvard Business Review (pp. 23-40).

Competitive Balance in Pro Sports Leagues: How does the NBA look? Retrieved October 30, 2013, from http://www.82games.com/balance.htm

FIFA (2003). Regulations on the Status and Transfer of Players. Retrieved October 30, 2013, from http://www.fifa.com/mm/document/affederation/administration/01/06/30/78/statusinhalt_en_122007.pdf

The Football League (2012). Financial Fair Play in The Football League. Retrieved October 30, 2013, from http://www.football-league.co.uk/page/FLExplainedDetail/0,,10794 2748246,00.html

UEFA (2009). The European Club Footballing Landscape, Club Licensing Benchmarking Report Financial Year 2009. Retrieved October 30, 2013, from http://www.uefa.com

UEFA (2010a). The European Club Footballing Landscape, Club Licensing Benchmarking Report Financial Year 2010. Retrieved October 30, 2013, from http://www.uefa.com

UEFA (2010b). UEFA Club Licensing and Financial Fair Play Regulations Edition 2010. Retrieved October 30, 2013, from http://www.uefa.com

UEFA (2012, 2013). Licensed to thrill. Benchmarking report on the clubs qualified and licensed to compete in the UEFA competition season 2013/2014. Retrieved October 30, 2013, from http://www.uefa.com

Vincze, G., Fügedi, B., Dancs, H., \& Bognár, J. (2008). The effect of the 1989-1990 political transition on the development and training of football talent in Hungary. Kinesiology 40(1), 50-60.

\section{AUTHOR'S ADDRESS: $\quad$ Lili Kassay}

University of Physical Education

Department of Sport Management

Budapest 1123, Hungary

E-mail: kassay@tf.hu

Received: 10 December 2015; Accepted: 25 January 2016 